\title{
Household disaster preparedness in the Islamic Republic of Iran: 2015 estimation
}

\author{
Ali Ardalan,,$^{1,2}$ Homa Yusefi, ${ }^{1,3}$ Narges Rouhi, ${ }^{3}$ Ahad Banar ${ }^{3}$ and Sanaz Sohrabizadeh ${ }^{4}$
}

${ }^{1}$ Department of Disaster and Emergency Health, School of Public Health, Tehran University of Medical Sciences, Tehran, Islamic Republic of Iran. ${ }^{2}$ Harvard Humanitarian Initiative, Harvard University, Cambridge, United States of America. ${ }^{3}$ Disaster Risk Management Office, Department of Public Health, Ministry of Health and Medical Education, Tehran, Islamic Republic of Iran. ${ }^{4}$ Department of Health in Disasters and Emergencies, School of Public Health and Safety, Shahid Beheshti University of Medical Sciences, Tehran, Islamic Republic of Iran (Correspondence to: Ali Ardalan: aardalan@ tums.ac.ir; ardalan@hsph.harvard.edu).

\begin{abstract}
Background: The Islamic Republic of Iran is at high risk of natural disasters. Households are the basic unit of society and they need to be prepared for disasters.

Aims: This study assessed disaster preparedness among Iranian households in 2015.

Methods: Using multistage cluster sampling, 2968 households in the catchment area of 53 public health departments in all 30 provinces of the Islamic Republic of Iran were surveyed on the disaster preparedness measures they had taken in the past year. The data collection questionnaire included 15 disaster preparedness measures. The mean preparedness score was calculated and its association with residence (urban versus rural), house ownership (owner versus renter) and education level of the head of the household (illiterate, elementary school, middle school, high school, university) was evaluated.

Results: The mean score for household disaster preparedness was 9.3 out of 100 ( $95 \%$ confidence interval: 8.3-10.3). Multivariate analysis showed higher preparedness among rural than urban households $(P=0.02)$. Higher education level was positively associated with a higher preparedness score $(P<0.001)$, as was house ownership $(P<0.001)$.

Conclusion: The level of household disaster preparedness in the Islamic Republic of Iran in 2015 was low. In line with the first priority for action of the Sendai Framework for Disaster Risk Reduction, the current study provides an overall picture of household disaster preparedness in the Islamic Republic of Iran. This estimation can be used as a baseline value for policy-making, planning, and evaluation of public awareness of disasters in the country.
\end{abstract}

Keywords: disasters, risk reduction behaviour, preparedness, households, Iran

Citation: Ardalan A; Yusefi H; Rouhi N; Banar A; Sohrabizadeh S. Household disaster preparedness in the Islamic Republic of Iran: 2015 estimation. East Mediterr Health J. 2020;26(4):382-387. https://doi.org/10.26719/emhj.19.048

Received: 08/01/17; accepted: 25/07/18

Copyright (c) World Health Organization (WHO) 2020. Open Access. Some rights reserved. This work is available under the CC BY-NC-SA 3.0 IGO license (https://creativecommons.org/licenses/by-nc-sa/3.o/igo).

\section{Introduction}

The Islamic Republic of Iran is at high risk of natural disasters. The Global Assessment Report on disaster risk reduction of 2009 put the country in the high multiple mortality risk class (8 out of 10) (1). Each year on average, natural disasters kill about 90000 people and affect 160 million people (2). Earthquakes, floods, drought and storms are the main natural disasters that affect the lives and livelihood of Iranians. To mitigate the risk of disasters, the country needs a national disaster preparedness programme that enables the community, including individuals, households, organizations and societies, to respond and recover effectively when disasters strike (3).

Lessons learnt from Iranian disasters and those learnt from other countries highlight the need for individual responsibility in disaster preparedness (3). Local people are the first who need to take protective actions when a disaster occurs. In addition, before the arrival of any professional response team, local people are the first responders to help their own families and neighbours, especially those with special needs and disabilities (4). Furthermore, studies have shown that citizen involvement is a key component in the natural hazard risk reduction (5), and that improving local preparedness will be effective only if people at risk know how to react appropriately (6).

In the past decade, the Islamic Republic of Iran has invested considerable effort to develop policies and infrastructure for disaster preparedness, including the establishment of the National Disaster Management Organization and strengthening of relief organizations (7). Nevertheless, the preparedness of local people is still a real concern and data on their level of preparedness are needed.

The aim of this study, therefore, was to estimate the level of disaster preparedness of Iranian households, in order to provide baseline figures for future assessment. We focused on the household as this is the most basic and fundamental unit of society. 


\section{Methods}

\section{Study design and sample selection}

A cross-sectional survey was conducted in December 2015 covering the catchment area of 54 public health departments in all 30 provinces of the Islamic Republic of Iran. Responses were received from 53 out of 54 (98.2\%) public health departments.

The household was the survey unit and was defined as a group of individuals living together under one roof. Multistage cluster sampling was used to select the sample of households. In the first stage, one district was randomly selected from each public health department. Then, two urban and two rural areas were randomly selected from the selected district. Finally, in each selected area, two random clusters of seven households were chosen using registries of households available at the corresponding primary health care centre. This resulted in the selection of 424 clusters including 2968 households.

\section{Survey tool and data collection}

Data collection was done using a questionnaire including 15 disaster preparedness measures. Households were asked if they had taken any of the measures over the past year with yes or no answers.

The questionnaire, called the household disaster preparedness index, was developed and validated for face and content validity by experts in health systems and disaster management. The content and face validity of the questionnaire was assessed and the Cronbach alpha for the awareness and readiness questions was 0.78 .

The survey protocol was piloted in four clusters $(28$ households) in one public health department, and was then revised according to the results of the pilot phase. Study variables were household disaster preparedness as the dependent variable, and residence (urban versus rural), house ownership status (owner versus renter), and education level of the head of the household (illiterate, elementary school, middle school, high school, university) as the independent variables.

A score of 1 was given for each preparedness activity undertaken. Unanswered questions answers were coded as o by default. Equal weight was given to each question. A raw score was calculated for preparedness questions by summing of all scores. Finally, preparedness raw scores were normalized on a 100-point scale. In the case of missing data, the field collection teams were sent back for clarification.

The survey was administered by the staff of disaster risk management offices at the public health departments. These staff were trained on the questionnaire, study protocol and interview skills. Each interview lasted about 20 minutes. Most often, the person interviewed was the head of the household, unless he or she was not available, in which case, another person older than 18 years of age was interviewed. If an appropriate household member was not at home at the time of the attempted interview, up to two further visits were made.

\section{Statistical analysis}

A complex sampling design was applied for the strata and clusters; urban and rural areas were considered as different strata. Mean and standard deviation of preparedness score were calculated along with the $95 \%$ confidence interval (CI). Independent $t$-test and ANOVA were applied to compare scores between and within the subgroups. Linear regression models were applied to assess the adjusted effects of variables on disaster preparedness. $P<0.05$ was considered statistically significant. SPSS, version 22.0 was used for statistical analysis.

\section{Ethical considerations}

This study was reviewed by the Disaster Risk Management Office of the Iranian Ministry of Health and Medical Education and considered exempt as no intervention was carried out and no sensitive data were collected.

\section{Results}

In this national survey, 2968 households (50\% urban and $50 \%$ rural) were assessed for disaster preparedness; 2527 households $(85.1 \%)$ were the owner of the houses they were living in, while $441(14.9 \%)$ were living in a rented house. The education level of the head of the household was as follows: $482(16.2 \%)$ illiterate, 738 (24.9\%) elementary school, 611 (20.6\%) middle school, 712 (24.0\%) high school and $425(14.3 \%)$ university.

The mean score of household disaster preparedness was at 9.3 out of 100 (95\% CI: 8.3-10.3). Table 1 presents the frequency of preparedness measures reported by the households that they had carried out over the past year.

The mean preparedness score was higher among rural households than urban households (9.5 versus 9.1, $P=0.02$ ) (Table 2). A slightly higher but statistically significant preparedness score was found in households that were the owners of the property they lived in compared with those who were living in a rented house (9.4 versus 9.3, $P<0.001)$. A higher level of education of the head of the household was positively associated with a higher preparedness score $(P<0.001)$ (Table 2$)$. The multivariate analysis also showed that all background variables were significantly associated with preparedness score $(P<$ 0.001) (Table 2).

\section{Discussion}

Our results indicate that household disaster preparedness is low in the Islamic Republic of Iran; only about 10 out of 100 households, on average, had taken any preparedness measures. Since this is the first national estimation, it is difficult to assess trends that have occurred over the past few years. Nevertheless, we speculate that household disaster preparedness has improved in the country in the past decade through improved public awareness facilitated by the media and community-based initiatives such as annual school drills.

Local people are on the frontline in a response to disasters. They are the first responders before the arrival of any professional team to the affected area. 


\begin{tabular}{lcc}
\hline Table 1 Disaster preparedness activities carried out over the past year by Iranian households & No. (n = 2968) & \% \\
Activity & 532 & 17.9 \\
Holding a family meeting for disaster planning & 107 & 3.6 \\
Drawing a household disaster risk map & 146 & 4.9 \\
Assessing structural safety of the house & 93 & 3.1 \\
Taking structural safety measures & 167 & 5.6 \\
Assessing non-structural safety of the house (e.g. furnishing, equipment, electrical and & 125 & 4.2 \\
mechanical fixtures) & 257 & 8.6 \\
Taking non-structural safety measures & 230 & 7.7 \\
Preparing an emergency kit & 346 & 11.6 \\
Having a disaster communication plan & 433 \\
Having a disaster evacuation plan & 496 & 14.6 \\
Planning for vulnerable members of the family & 376 & 16.7 \\
Being aware of early warning for hydroclimatic hazards (e.g. flooding) & 427 \\
Having a fire extinguisher in the house & 194 & 12.7 \\
At least one of the household member being trained on medical first aid & 206 \\
Contributing to neighbourhood disaster planning & \\
Carrying out a disaster exercise & & 6.5 \\
\hline
\end{tabular}

Furthermore, preparedness of local people reduces the effect of disasters and associated risks of death and injuries. Such local preparedness includes having an emergency kit ready, conducting regular drills, assisting vulnerable people and having a communications plan. Lessons learnt from disasters around the world highlight the need for individual responsibility and local coordination in response to and recovery from disasters (3). The literature highlights the importance of household and individual preparedness for natural disasters (8,9). Enhanced awareness of people and involvement of citizens in disaster planning is also a strategy that must be incorporated into public values to improve the sustainability of decisions (10). This is why national governments initiate plans to enhance disaster preparedness at the community level (3).

A household, by definition, is a place where a group of individuals lives under the same roof. As an important component of the community preparedness for disasters, we focused on households. This is because a household, mostly shaped by members of a family, is the basic unit of society and is a place where members support each other and learn from one another. Each individual interacts with other family members and can both affect others and/or be affected by them. These characteristics can be utilized for community disaster preparedness.

Because of the frequent devastating natural disasters in the Islamic Republic of Iran and the coverage by the media, we can expect the Iranian community to be well-

\begin{tabular}{|c|c|c|c|c|c|}
\hline \multirow[t]{2}{*}{ Group } & \multirow[t]{2}{*}{ Mean (SD) } & \multirow{2}{*}{$\begin{array}{c}\text { Bivariate analysis } \\
\text { P-value }^{\mathrm{a}}\end{array}$} & \multicolumn{3}{|c|}{ Multivariate analysis } \\
\hline & & & B & $\mathbf{t}$ & P-value ${ }^{a}$ \\
\hline \multicolumn{6}{|l|}{ Residence } \\
\hline Urban & 9.1 (9.01) & 0.02 & 0.079 & 3.021 & $<0.001$ \\
\hline Rural & $9.5(9.04)$ & & & & \\
\hline \multicolumn{6}{|c|}{ House ownership } \\
\hline Owner & $9.4(9.02)$ & $<0.001$ & 0.001 & 0.072 & $<0.001$ \\
\hline Rental & $9.3(9.04)$ & & & & \\
\hline \multicolumn{6}{|c|}{ Education of family head } \\
\hline Illiterate & $8.1(8.31)$ & $<0.001$ & 0.002 & 6.047 & $<0.001$ \\
\hline Elementary & $9.1(9.14)$ & & & & \\
\hline Middle & $9.2(8.23)$ & & & & \\
\hline High school & $9.3(9.33)$ & & & & \\
\hline University & $10.3(9.52)$ & & & & \\
\hline
\end{tabular}

SD: standard deviation.

aP values are calculated based on the complex sampling design. 
sensitized and informed about the risks of disasters, especially earthquakes and floods. However, the low preparedness we found, measured as the practical steps taken by the households, shows there is still a gap between what people know and what they do (11). This requires further studies to investigate factors that contribute to this gap.

Preparedness of households for emergency situations depends on complex and multifaceted factors (12). Having sufficient knowledge of how to prepare for emergencies does not guarantee that people will implement selfprotection measures (13). The positive association between past disaster experience and preparedness of households has been found in several studies $(14,15)$. However, other research suggests that past disaster experience is not the prime factor that enhances awareness and that school education can provide useful information as a knowledge base for earthquakes (16).

Risk perception is another key factor that determines if people undertake preparedness measures $(9,14)$. Risk perception also affects how people think about sharing responsibility with governmental organizations (9). Research suggests that some households may not be able to prepare for disasters because of a lack of resources (3). This vulnerability may be associated with income, education, ethnicity, age and linguistic isolation. Other research has suggested that those most likely to engage in self-protective behaviour for earthquakes are those living in safer and structurally sounder houses (17). Two studies in Tehran suggest that in order to promote disaster preparedness behaviour, there needs to be a focus on people of low socioeconomic background (11,15). Factors such as income influence access to safe housing, insurance and other resources required for safety measures, such as preparation of emergency kits $(3,18)$. Therefore, limitations on household resources should be taken into consideration when advocating safety measures (17).

People may also overestimate their preparedness $(8,19)$. A study in Queensland, Australia, found that while two out of every three households believed they were prepared or very prepared for a natural disaster, their responses to more detailed questions on preparedness suggested otherwise (19). In our study, the participants expressed low basic preparedness.

Following the 2003 earthquake in Bam, the Islamic Republic of Iran invested considerably in public awareness through the national media. Iranian television and radio channels have produced programmes, such as reports, expert interviews and animations, and have presented them on special occasions, including the anniversary of the Bam earthquake and the National Day of Disaster Reduction. Moreover, an annual earthquake drill is held at schools by the Ministry of Education and the International Institute of Earthquake Engineering and Seismology (20,21). In addition, a neighbourhood disaster preparedness programme has also been developed by the Tehran Disaster Prevention and Management Organization and expanded to other cities (22).
According to the National Disaster Management Organization, the Iranian Red Crescent Society is the lead agency for the disaster public awareness. While the Iranian Red Crescent Society has carried out many activities, including training volunteers and conducting community drills, raising public awareness of disaster management is a difficult task to be managed entirely by one agency. The working group has to make use of the capacities of all governmental bodies and civil societies to create better preparedness.

The Iranian public health system, led by the Ministry of Health and Medical Education, is a key and trusted partner in community disaster preparedness $(23,24)$. Not only has it taken an initiative to measure household disaster preparedness, but it has also utilized the capacity of the primary health care system to educate households in collaboration with community health volunteers. As a result of this initiative, over 500000 households had received training by the end of 2015 (25). The programme continued in 2016 and is now well integrated into the primary health care system in the Islamic Republic of Iran. Under this programme, each household should have a household disaster preparedness index form in their respective health centre files. Quantifying household disaster preparedness, as presented in this article, provided supporting evidence and was a driving force behind the creation of this programme.

\section{Conclusion}

In line with the first priority for action of the Sendai Framework for Disaster Risk Reduction, which is understanding the risk (26), our study provides an overall picture of household disaster preparedness in the Islamic Republic of Iran. Although the findings of our study support the first priority for action in the Sendai Framework, it can indirectly influence the other three priorities namely: strengthening disaster risk governance, investing in disaster risk reduction for resilience and enhancing disaster preparedness for effective response and to "Build Back Better" in recovery. For example, our estimation of household disaster preparedness can help communities to identify and fill their preparedness gaps and enhance disaster preparedness. This estimation can be used as a baseline value for policy-making, planning and evaluation of disaster public awareness and help strengthen disaster risk governance in the country. Assessment of household disaster preparedness should be repeated on a regular basis, preferably annually, to monitor the effectiveness of interventions to improve preparedness. Further research is needed to explore different aspects of household disaster preparedness, including political sensitivities and legal frameworks to support community preparedness, risk analysis, evacuation plans and community safety, health sector community preparedness and environmental health.

Funding: The survey was supported by the Ministry of Health and Medical Education of the Islamic Republic of Iran.

Competing interests: None declared. 


\section{Préparation des ménages en cas de catastrophe naturelle en République islamique d'Iran : estimation pour l'année 2015}

\section{Résumé}

Contexte: La République islamique d'Iran est exposée à un risque élevé de catastrophes naturelles. Les ménages constituent la cellule de base de la société et ils doivent être prêts à faire face à des catastrophes de ce type.

Objectifs : La présente étude a évalué la préparation des ménages iraniens en cas de catastrophe naturelle en 2015.

Méthodes : En utilisant un sondage en grappes à plusieurs degrés, 2968 ménages appartenant à la zone couverte par 53 départements de santé publique dans les 30 provinces de la République islamique d'Iran ont été interrogés sur les mesures de préparation face aux catastrophes naturelles qu'ils avaient mises en place au cours de l'année précédente. Le questionnaire de collecte de données comprenait 15 mesures de préparation aux catastrophes. Le score moyen de préparation a été calculé et son association avec le lieu de résidence (milieu urbain ou rural), le fait d'être propriétaire de son logement (propriétaire ou locataire) et le niveau d'éducation du chef de ménage (analphabète, primaire, collège, lycée, université) a été évaluée.

Résultats : Le score moyen de préparation des ménages aux catastrophes était de 9,3 sur 100 (intervalle de confiance à $95 \%$ : 8,3-10,3). L'analyse multivariée a montré un niveau de préparation plus élevé parmi les ménages des milieux ruraux que parmi ceux vivant en milieu urbain $(p=0,02)$. Le niveau d'éducation plus élevé était associé de façon positive à un score de préparation supérieur $(p<0,001)$ de même que le fait d'être propriétaire de son logement $(p<0,001)$.

Conclusion : En 2015, le niveau de préparation des ménages face aux catastrophes naturelles en République islamique d'Iran était faible. En ligne avec la première priorité d'action du Cadre de Sendai pour la réduction des risques de catastrophe, la présente étude offre une vue d'ensemble de la préparation des ménages aux catastrophes en République islamique d'Iran. Cette estimation pourrait constituer une base de référence en vue de l'élaboration des politiques, de la planification et de l'évaluation du niveau de sensibilisation du public face aux catastrophes naturelles dans le pays.

$$
\begin{aligned}
& \text { التأهب الأسري للكوارث في جمهورية إيران الإسلامية: تقييم عام } 2015 \\
& \text { علي أردلان، هما يوسفي، نرجس روحي، الخاب، احد بنار، ساناز سهرابي زادة } \\
& \text { الخُلاصة }
\end{aligned}
$$

الخلفية: تواجه جمهورية إيران الإسلامية خطر المرتفعا جرّاء التعرض للكوارث الطبيعة. وتشكل الأسرة الوحدة الأساسية للمجتمع، لذا فهي بحاجة إلى التأهب للكوارث. تؤه

$$
\text { الأهداف: قيمت هذه الدراسة درجة التأهب للكوارث لدى الأسر الإيرانية في عام } 2015 .
$$

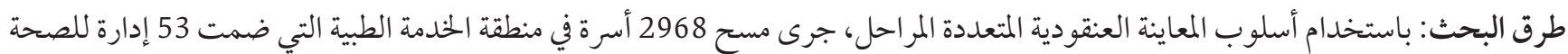

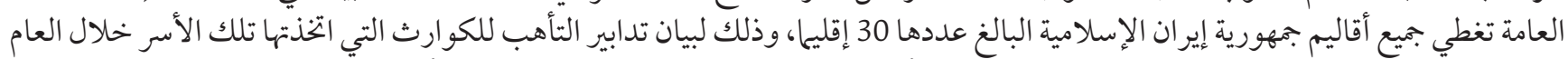

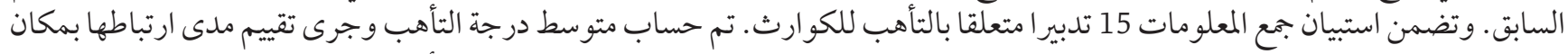

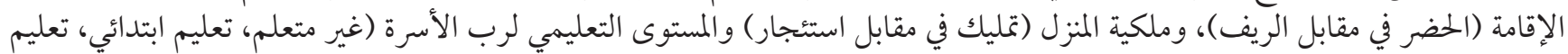

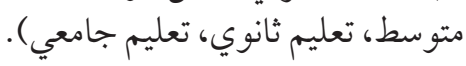
النتائج: كان متوسط درجة تأهب الأسر 9.3 من 100 درجة (10.3 - 95\% CI =8.3) ـ و أظهر التحليل المتعدد المتغيرات تأهبا لدى الأسر في الأماكن

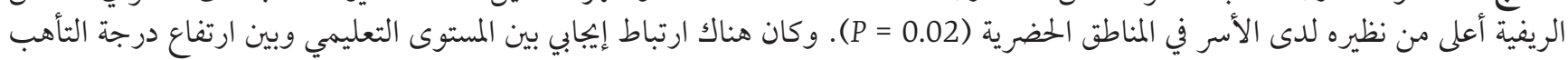

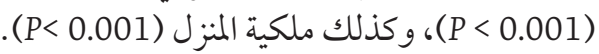

الاستنتاج: مستوى التأهب الأسري للكوارث في جمهورية إير ان الإسلامية في عام 2015 كان منخفضا. وتماشيا مع الأولوية الأولى للعمل وفق إطار

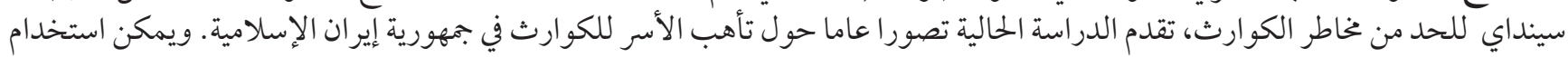

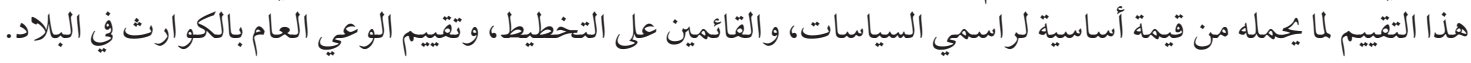

\section{References}

1. United Nations International Strategy for Disaster Reduction (UNISDR). Global assessment report on disaster reduction. Geneva: United Nations; 2009.

2. Environmental health in emergencies. Natural events [webpage]. World Health Organization (https://www.who.int/environmental_health_emergencies/natural_events/en/, accessed 11 September, 2018).

3. Sutton J, Tierney K. Disaster preparedness: concepts, guidance, and research. 2006. (http://www.fritzinstitute.org/pdfs/whitepaper/disasterpreparedness-concepts.pdf, accessed 11 August, 2016). 
4. Uscher-Pines L, Hausman AJ, Powell S, DeMAra P, Heake G, Hagen MG. Disaster preparedness of households with special needs in southeastern Pennsylvania. Am J Prev Med. 2009;37(3):227-30. https://doi.org/10.1016/j.amepre.2009.04.028

5. Household natural hazards preparedness survey. Eugene: Oregon Natural Hazards Workgroup; 2006 (accessed 24 September 2019).

6. Liu S, Quenemoen LE, Malilay J,Noji E, Sinks T, Mendlein J. Assessment of a severe-weather warning system and disaster preparedness, Calhoun county, Alabama, 1994. Am J Public Health. 1996;86(1):87-9. https://doi.org/10.2105/ajph.86.1.87

7. Ardalan A, Masoomi GR, Goya M, Ghaffari M, Miadfar J, Sarvar MR, et al. Disaster health management: Iran's progress and challenges. Iranian J Public Health. 2009;38(suppl 1):93-7.

8. Kapucu N. Culture of preparedness: household disaster preparedness. Disaster Prev Manag. 2008;17(4):526-35. https://doi. org/10.1108/09653560810901773

9. Terpstraa T, Guttelinga JM. Households' perceived responsibilities in flood risk management in the Netherlands. Int J Water Resour Dev. 2008;24(4):555-65. https://doi.org/10.1080/07900620801923385

10. Beierle T. Using social goals to evaluate public participation in environmental decisions. Political Stud. Rev. 1999;16(3/4):75-103. https://doi.org/10.1111/j.1541-1338.1999.tboo879.x

11. Ostadtaghizadeh A, Hosseini M, Navidi I, Asghar Mahaki A, Ammari H, Ardalan A. Knowledge, attitude and practice of Tehran's inhabitants for an earthquake and related determinants. PLoS Curr. 2012;4:e4fbbbe1668eef. https://doi.org/10.1371/4fbbbe1668eef.

12. Kohn S, Eaton JL, Feroz S, Bainbridge AA, Hoolachan J, Barnett DJ. Personal disaster preparedness: An integrative review of the literature. Disaster Med Public Health Prep. 2012;6(03):217-31. https://doi.org/10.1001/dmp.2012.47.

13. Diekman ST, Kearney SP, O’Neil ME, Mack KA. Qualitative study of homeowners' emergency preparedness: Experiences, perceptions, and practices. Prehospital Disaster Med. 2007;22(06):494-501.

14. Ardalan A, Holakouie Naieni K, Mahmoud M, Zanaganeh A-M. Flash flood preparedness in Golestan province of Iran: a community intervention trial. Am J Disaster Med. 2010;5(4):197-214.

15. Najafi M, Ardalan A, Akbarisari A,Noorbala AA, Jabbari H. Demographic determinants of disaster preparedness behaviors amongst Tehran inhabitants, Iran. PLoS Curr. 2015;7. https://doi.org/10.1371/currents.dis.976boab9c9d9941cbbae3775a6c5fbe6

16. Shaw R, Kobayashi KSH, Kobayashi M. Linking experience, education, perception and earthquake preparedness. Disaster Prev Manag. 2004;13(1):39-49. https://doi.org/10.1108/09653560410521689

17. Edwards ML. Social location and self-protective behavior: Implications for earthquake preparedness. Int J Mass Emergencies Disasters. 1993;11(3):293-303.

18. Ardalan A, Sohrabizadeh S. Assessing households preparedness for earthquakes: an exploratory study in the development of a valid and reliable Persian-version tool. PLOS Curr. 2016;8. https://doi.org/10.1371/currents.dis.ccc8697279713e66887b928b839dog20.

19. Queensland Regional Household Survey, May 2012. Queensland: Office of Economic and Statistical Research; 2012 (https://www. disaster.qld.gov.au/dmp/Archive/Documents/QRHS-May-2012-EMQ-Survey-Report-FINAL-VERSION-04-10-12.pdf.

20. Izadkhah YO, Hosseini M. Towards resilient communities in developing countries through education of children for disaster preparedness. Int J Emerg Manag. 2005;2(3):138-48. https://doi.org/10.1504/IJEM.2005.007355

21. Parsizadeh F, Ghafory-Ashtiany M. Iran public education and awareness program and its achievements. Disaster Prev Manag. 2010;19(1):32-47. https://doi.org/10.1108/09653561011022126

22. Tehran neighbourhood emergency response volunteers. Tehran: Tehran Disaster Mitigation and Management Organization; 2012. (http://en.tehran.ir/Portals/o/Document/Tehran\%20Neighbourhood\%20Emergency\%20Response\%20Volunteers.pdf, accessed 11 August, 2016).

23. Ardalan A, Mowafi H, Burkle FM Jr. Iran's disaster risk: now is the time for community-based public health preparedness. Prehosp Disaster Med. 2013;28(5):421-2. https://doi.org/10.1017/S1049023X13008820.

24. Ardalan A, Mowafi H, Malekafzali H, Abolhasani F. Effectiveness of a primary health care program on urban and rural community disaster preparedness, Islamic Republic of Iran: a community intervention trial. Disaster Med Public Health Prep. 2013;7(5):481-90. https://doi.org/10.1017/dmp.2013.93.

25. Ardalan A, Yousefi H, Rouhi N, Banar A. National report on household disaster preparedness. Tehran: Disaster Risk Management Office, Ministry of Health and Medical Education; 2015.

26. United Nations International Strategy for Disaster Reduction. Sendai framework for disaster risk reduction 2015-2030. Geneva: United Nations; 2015 (http://www.unisdr.org/we/inform/publications/43291, accessed 11 August, 2016). 